EPJ Web of Conferences 45, 01106 (2013)

DOI: $10.1051 /$ epjconf/20134501106

(C) Owned by the authors, published by EDP Sciences, 2013

\title{
Experimental Performance Investigation of Photovoltaic/Thermal (PV-T) System
}

\author{
M. Ozgoren ${ }^{1, \mathrm{a}}$, M. H. Aksoy², C. Bakir ${ }^{3}$, and S. Dogan ${ }^{4}$ \\ ${ }^{1,2,4}$ Selcuk University, Engineering Faculty, Mechanical Engineering Department, Konya, Turkey \\ ${ }^{3}$ Solimpeks Solar Energy Systems Company, Konya, Turkey
}

\begin{abstract}
Photovoltaic solar cells convert light energy from the sun into electricity. Photovoltaic cells are produced by semi-conducting materials to convert the energy into electricity and during this process heat is absorbed by the solar radiation. This heat causes a loss of electricity generation efficiencies. In this study, an experimental setup was designed and established to test two separate photovoltaic panel systems with alone PV and with water cooling system PV/T to examine the heat effect on PV systems. The absorbed heat energy behind the photovoltaic cell's surface in insulated ambient was removed by means of a water cooling system and the tests for both systems were simultaneously performed along the July 2011. It is found that without active water cooling, the temperature of the PV module was higher during day time and solar cells could only achieve around $8 \%$ conversion efficiency. On the other hand, when the PV module was operated with active water cooling condition, the temperature dropped significantly, leading to an increase in the efficiency of solar cells as much as $13.6 \%$. Gained from absorbed solar heat and maximum thermal conversion efficiencies of the system are determined as $49 \%$ and $51 \%$ for two different mass flow rates. It is observed that water flow rate is effective on the increasing the conversion efficiency as well as absorption and transition rates of cover glass in PV/T (PV-Thermal) collector, the insulation material and cell efficiency. As a conclusion, the conversion efficiency of the PV system with water cooling might be improved on average about $10 \%$. Therefore, it is recommended that PV system should be designed with most efficient type cooling system to enhance the efficiency and to decrease the payback period.
\end{abstract}

\section{Nomenclature}

\begin{tabular}{llll}
\hline $\mathrm{A}_{\mathrm{m}}$ & Area of PV module $\left(\mathrm{m}^{2}\right)$ & $\mathrm{U}_{\mathrm{L}}$ & Overall heat loss coefficient $\left(\mathrm{W} / \mathrm{m}^{20} \mathrm{C}\right)$ \\
$\mathrm{C}_{\mathrm{f}}$ & Fluid specific heat $\left(\mathrm{kcal} / \mathrm{kg}{ }^{0} \mathrm{C}\right)$ & $\mathrm{W}$ & Width of the tube spacing $(\mathrm{m})$ \\
$\mathrm{D}$ & Diameter of cupper tube $(\mathrm{m})$ & $\alpha$ & Absorbtivities of glass \\
$\mathrm{F}$ & Fin efficiency factor & $\beta_{0}$ & PV temperature coefficient $\left({ }^{0} \mathrm{C}^{-1}\right)$ \\
$\mathrm{F}^{\prime}$ & Flat plate collector efficiency factor & $\delta$ & Plate thickness $(\mathrm{m})$ \\
$\mathrm{F}_{\mathrm{R}}$ & Flow rate factor & $\Delta \mathrm{T}$ & Temperature difference $\left({ }^{0} \mathrm{C}\right)$ \\
$\mathrm{I}_{\mathrm{t})}$ & Solar radiation $\left(\mathrm{W} / \mathrm{m}^{2}\right)$ & $\eta_{\mathrm{t}}$ & Thermal efficiency of PV/T collector \\
$\dot{\mathrm{m}}$ & Fluid flow rate $\left(\mathrm{kg} / \mathrm{m}^{3}\right)$ & $\eta_{0}$ & Overall efficiency of PV/T collector \\
$\mathrm{T}_{\mathrm{fi}}$ & Fluid inlet temperature $\left({ }^{0} \mathrm{C}\right)$ & $\eta_{\mathrm{e}}$ & Electrical efficiency \\
$\mathrm{T}_{\mathrm{fo}}$ & Fluid outlet temperature $\left({ }^{0} \mathrm{C}\right)$ & $\eta_{\mathrm{c}}$ & PV cell efficiency \\
$\mathrm{T}_{\mathrm{c}}$ & PV cell temperature $\left({ }^{0} \mathrm{C}\right)$ & $\tau$ & Transmissivity of glass \\
$\mathrm{T}_{\mathrm{a}}$ & Ambient temperature $\left({ }^{0} \mathrm{C}\right)$ & & \\
\hline
\end{tabular}

\section{Introduction}

In the context of greenhouse gas emissions and fossil resources depletion, solar energy is one of the most promising sources among renewable energy sources. Nowadays, electricity generation from solar energy is very attractive in Turkey due to the recent regulation laws about renewable energy usage. Electric energy conversion efficiencies of the commercially available photovoltaic (PV) panels are in the range of $10-20 \%$ depending on its physical and chemical properties. It means more than $80-90 \%$ of the solar radiation falling on

\footnotetext{
${ }^{\mathrm{a}}$ mozgoren@selcuk.edu.tr
} 
photovoltaic (PV) cells is not converted to electric energy, but either reflected or converted to thermal energy. This leads to an increase in the PV cell's operating temperature and consequently, a drop of electricity conversion efficiency due to the significant reduction in the open circuit voltage of each PV cell [1]. For monocrystalline (c-Si) and polycrystalline (pc-Si) silicon solar cells, the electrical efficiency decreases by about $0.45 \%$ for every degree rise in temperature. For amorphous silicon (a-Si) cells, the effect is less, with a decrease of about $0.25 \%$ per degree rise in temperature depending on the module design [2]. Therefore, in order to obtain variable level conversion efficiency, module temperature should be kept as low as possible [1].

Solar water heating systems use heat from the sun to warm domestic hot water. A conventional boiler or immersion heater can be used to make the water hotter, or to provide it when solar energy is unavailable. In view of both hot water and electricity generation, hybrid of photovoltaic and thermal $(\mathrm{PV} / \mathrm{T})$ collectors is introduced to generate electricity and thermal power simultaneously. $\mathrm{PV} / \mathrm{T}$ modules have the ability to generate more energy per unit surface area than side by side PV panels and solar thermal collectors, at a lower production and installation cost. Because of its high efficiency per unit surface area, PV/T is particularly well suited for applications with both heat and power demand [4,5]. In the Netherlands it is showed by ECN (Energy Research Centre of the Netherlands) that with the use of PV/T collectors it was possible to reduce the total collector area by $40 \%$ while generating the same amount of energy [6].

In $\mathrm{PV} / \mathrm{T}$ systems, the reduction of $\mathrm{PV}$ module temperature can be combined with useful fluid heating. These systems consist of PV modules coupled to heat extraction devices in which air or water at lower temperature than PV modules while at the same time, the PV module temperature is reduced. Natural or forced air circulation is simple and low cost methods to remove heat from PV modules, but it is less effective if the ambient air temperature is over $20^{\circ} \mathrm{C}$. To overcome this, the heat can be extracted by circulating water through a heat exchanger that is mounted at the rear surface of the PV module [1,2].

On the other side, the thermal efficiency of a PV/T collector is lower than for a traditional system [7] for many reasons: a part of solar energy is converted into electricity, the optical factor is weaker (lower absorption coefficient) and the global coefficient of the thermal losses is higher [8,9]. But for PV/T system applications electricity generation efficiency is considered more important than thermal efficiency. Some of the studies about PV/T systems are given and cited therein. Although there are different types of the system, two main families of $\mathrm{PV} / \mathrm{T}$ devices can be identified: concentrated $\mathrm{PV} / \mathrm{T}$ collectors [10,11] and flat plate PV/T collectors. As reported by different authors in recent reviews [12-15], many configurations of flat plate $\mathrm{PV} / \mathrm{T}$ collectors have been developed. They differ from each other according to whether an additional glass cover: $[16,17]$ and the nature of the heat transfer fluid. Several studies have been performed on water $[8,18,19]$, air [20-22] and a few on bi-fluid [23]. In this work, our field of interest is the water type collector. Some studies about PV/T water systems given in detail as follows.

Dubey and Tiwari [24] designed an integrated photovoltaic (glass-to-glass) thermal (PV/T) solar water heater system and tested it in outdoor conditions of India. Similarly, Erdil et al. [25] constructed and tested a hybrid $\mathrm{PV} / \mathrm{T}$ system for energy collection at geographical conditions of Cyprus, where water was used as the cooling fluid. It was reported that the payback period for their proposed modification was less than 2 years which made their hybrid system economically attractive. Chow et al. [19] developed a numerical model of a photovoltaic thermosyphon collector system using water as a working fluid and verified the model accuracy by comparing with measured data. They examined the energy performance of the collector system with a reduced-temperature analysis method. It is stated that equipment is capable of extending the PV application potential in the domestic sector. A novel heat-pipe photovoltaic/thermal system was designed and constructed by Gang et al. [26]. Their results indicated that the daily thermal and electrical efficiencies of the heat-pipe PV/T system were $41.9 \%$ and $9.4 \%$, respectively, while the average heat and electrical gains were $276.9 \mathrm{~W} / \mathrm{m}^{2}$ and $62.3 \mathrm{~W} / \mathrm{m}^{2}$.

Some more advantages of $\mathrm{PV} / \mathrm{T}$ collectors are pointed out, as follows, by Zondag et. al. [13] and Sandnes and Rekstad [7];

- Economical order compared to a combination of separate thermal and photovoltaic panels;

- The area covered with a hybrid solar collector produces more electrical and thermal energy than a corresponding area half covered with standard PV panels and half with a conventional thermal collector.

- The average temperature of operation for a hybrid collector being generally lower than for a standard PV module, its electrical production will be increased and this provides long life time of material.

- A PV/T collector provides architectural uniformity.

Figure 1 shows the sketch of the single glazed flat plate PV/T collector based on water cooling used in the present experimental setup. In this PV/T concept PV cells operate as a thermal absorber. The main disadvantage of this system: the glass cover reduces the performance of the PV by both generating optical loss and leading to an increase of the cell temperature by greenhouse effect. In the present study, an experimental setup with and without water cooling system on PV panels was designed and established to investigate cooling effect on PV systems at environmental conditions.

\section{Material and Method}

In the experimental setup a $190 \mathrm{~W}$ PV and a $190 \mathrm{~W}$ PV/T water panels were established in the garden of Solimpeks Energy Company in Konya province of Turkey in order to find the module's electrical and thermal performance. Photograph of the test unit is given in figure 2 . 

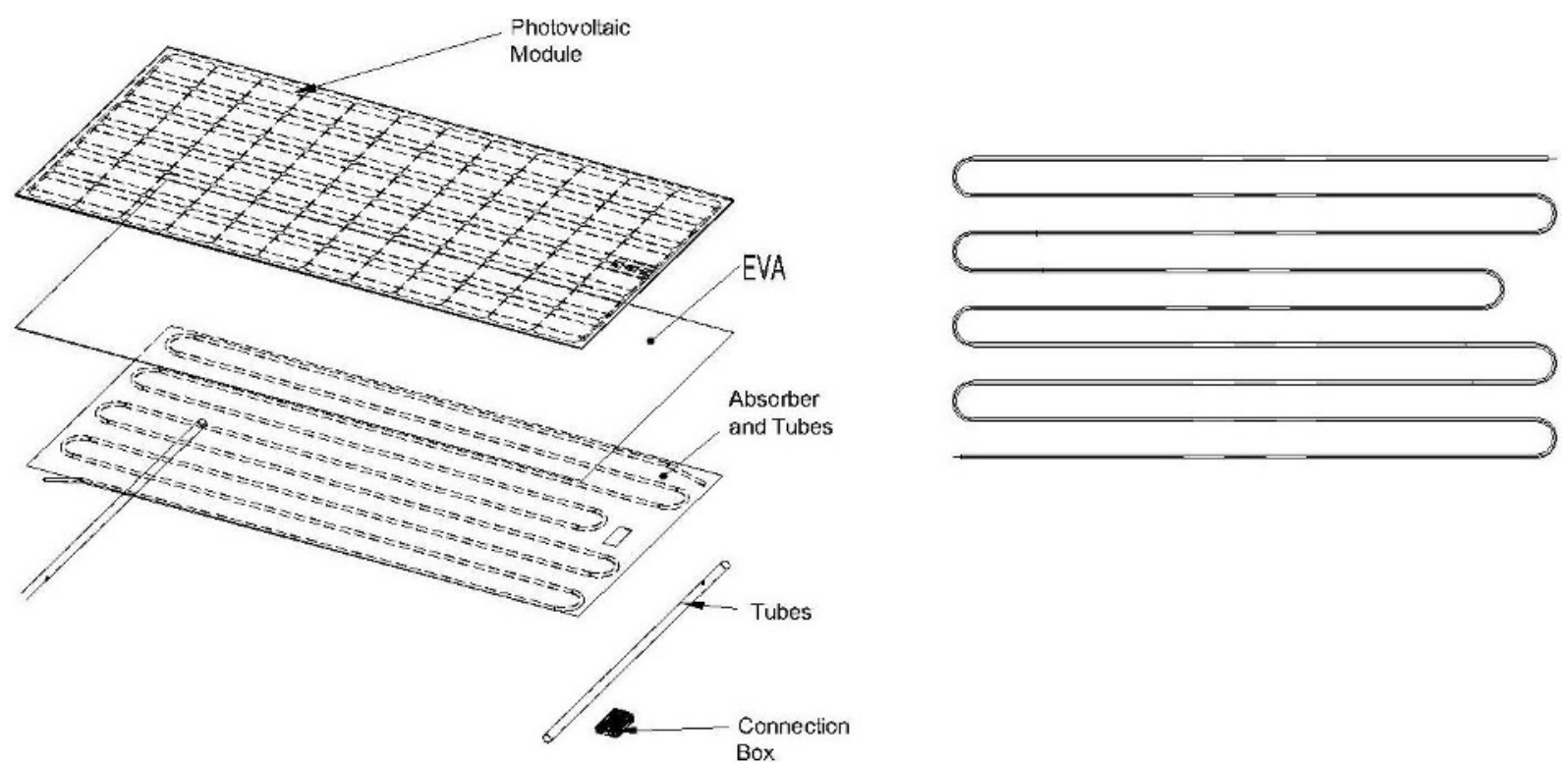

Fig. 1. The photovoltaic/thermal solar collector

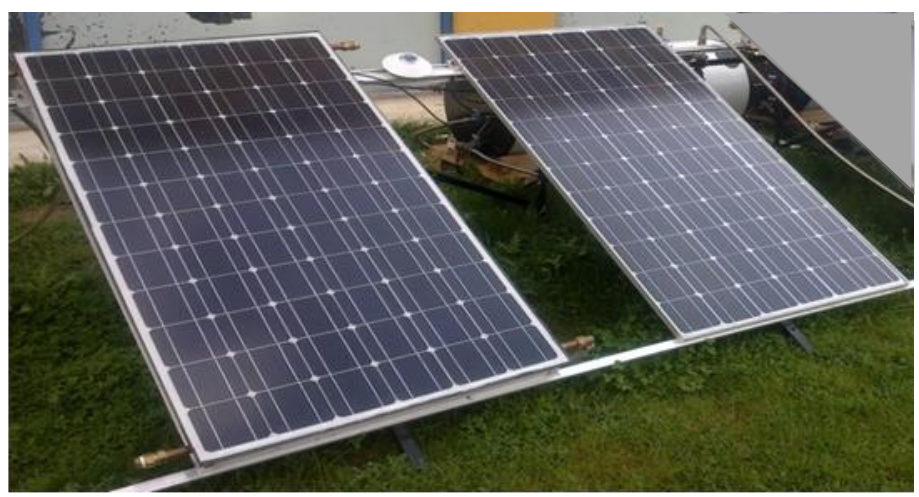

Fig. 2. $\mathrm{PV}$ and $\mathrm{PV} / \mathrm{T}$ test unit. Left side collector is $\mathrm{PV} / \mathrm{T}$ and right side collector is $\mathrm{PV}$

The cell types used in the PV and PV/T systems are mono-crystalline and they both connected to separate charge control devices and dataloggers. The dataloggers are used to store generated current, accumulator's voltage every second and stored it in one minute period and also send all data to a computer simultaneously. Generated electricity by the system is directed to charge controllers then to the accumulators. In order to measure the temperature at inlet, outlet of the $\mathrm{PV} / \mathrm{T}$, storing tank of collector and ambient temperature, the calibrated copperconstantan thermocouples are used. The temperatures are measured with temperature sensors (PT100). Hourly solar radiation on flat plate collectors have also been measured by using a pyronometer with the same angle with PV and $\mathrm{PV} / \mathrm{T}$ collectors. All specifications of the used devices in the system are given in table 1 .

Table 1. Specifications of the examined PV/T system

\begin{tabular}{|l|l|}
\hline PV/T Collector & Collector Dimensions: 828x1660x105 mm \\
& Absorber Material: Cupper \\
& Absorber Type: Tube-Sheet \\
& Effective area: $1.222 \mathrm{~m}^{2}$ \\
& Module Power: $190 \mathrm{~W}$ \\
\hline PV Module & Module Dimensions: $1580 \mathrm{x} 808 \mathrm{~mm}$ \\
& Cell Area: $1.125 \mathrm{~m}^{2}$ \\
& Cell Type: Mono-crystallin \\
& Conversion Efficiency: $16 \%$ \\
& Module Power: $190 \mathrm{~W}$ \\
\hline Water Storage Tank & Type: Cylindrical vertical \\
& Capacity: $175 \mathrm{lt}$ \\
\hline Battery & Thermal insulation: $50 \mathrm{~mm}$ thick cotton wool \\
& Rated Power: $12 \mathrm{~V}$ \\
& Capacity: $200 \mathrm{Ah}$ \\
& Unit: 2 Series \\
\hline
\end{tabular}




\begin{tabular}{|l|l|}
\hline Charge Controller & Rated input voltage: $24 \mathrm{~V}$ \\
& Rated input current: $35 \mathrm{Ah}$ \\
& Data logger Connection: Cat5 \\
\hline Data Logger(Electrical) & System voltage: $12 \mathrm{~V} / 24 \mathrm{~V} / 48 \mathrm{~V}$ \\
& Logger capacity: 1 Mbit=2 min \\
& Recorded values: relative time, total charge current, solar module \\
& current, battery voltage, system status \\
& Interfaces: RS232 \\
\hline Data Logger (Thermal) & Inputs: 6 x temperature (Pt100) \\
& Outputs: $2 \times$ triac for speed control \\
& Interfaces: SD card or RS232 \\
& Data logging: SD card \\
\hline
\end{tabular}

\subsection{Experimental conditions}

In this study, electricity current, voltage, module temperature, ambient temperature, inlet and outlet water temperatures, solar radiation were measured. Table 2 shows the installation conditions of the PV/T collector. The tilt angles of all the plates, including the PV/T collector and PV module was $30^{\circ}$, which received the maximum solar radiation for Konya province with respect to the yearly total solar radiation amount.

Table 2. Installation condition of the experimental setup

\begin{tabular}{|l|l|}
\hline Location & Karatay/Konya/Turkey \\
\hline Latitude & $37^{0} \mathrm{~N}$ \\
\hline Longitude & $32^{0} \mathrm{E}$ \\
\hline Tilt angle & $30^{0}$ \\
\hline Direction & South \\
\hline
\end{tabular}

\subsection{Energy balance equations}

In order to write the energy balance equation for each component of a combined system of PV/T solar collector, the following assumptions have been made:

- The heat capacity of PV/T collector has been neglected in comparison with the heat capacity of water in the storage tank.

- There is no temperature stratification in the water of the storage tank due to forced mode of operation.

- One dimension heat conduction is considered.

- The system is in quasi-steady state.

- The ohmic losses in the solar cell are negligible [24].

The term total efficiency $\eta_{\mathrm{o}}$ has been widely used in the performance evaluation of PV/T system $[4,27,28]$, i.e.

$$
\eta_{0}=\eta_{\mathrm{e}}+\eta_{\mathrm{t}}
$$

Where $\eta_{\mathrm{t}}$ and $\eta_{\mathrm{e}}$ are, respectively, the thermal efficiency and electrical-power generation efficiency of the PV/T system. Considering electrical energy as higher in grade form than thermal energy. The flow rate factor $\left(F_{R}\right)$ is given by;

$$
F_{R}=\frac{\dot{m} C_{f}}{A_{m} U_{L}}\left[1-\exp \left(\frac{A_{m} U_{L} F^{\prime}}{\dot{m} C_{f}}\right)\right]
$$

The flat-plate collector efficiency, $F^{\prime}$, is given by Duffie and Beckman [29] and Tiwari [30];

$$
F^{\prime}=\frac{1}{\frac{W x U_{L}}{\pi D h}+\frac{W}{D+(W-D) F}}
$$

Here, $\mathrm{F}$ is the fin efficiency which can be estimated using the following expression;

$$
F=\frac{\tanh \left[\sqrt{\frac{U_{L}}{K \delta}}(W-D)\right] / 2}{\left[\sqrt{\frac{U_{L}}{K \delta}}(W-D)\right] / 2}
$$

Overall heat loss coefficient $\left(\mathrm{U}_{\mathrm{L}}\right)$ and thermal efficiency of the PV/T system $\left(\eta_{t}\right)$ are given by Vokas [31];

$$
U_{L}=\left(\alpha \cdot \tau \cdot I_{(t)}+\eta_{c} \cdot I_{(t)}\right) /\left(T_{c}+T_{a}\right)
$$

According to the defined variables

$$
\eta_{l}=F_{R} \cdot(\alpha \tau)_{\text {verim }}-\mathrm{F}_{\mathrm{R}} \cdot U_{L} \frac{\left(T_{a}-T_{f i}\right)}{I(t)}
$$

An expression for temperature dependent electrical efficiency of a PV module [32,33] and cell temperature $\left(\mathrm{T}_{\mathrm{c}}\right)$ are given;

$$
\begin{gathered}
\eta_{e}=\eta_{h}\left(1-\beta_{0}\left(T_{h}-25\right)\right. \\
T_{c}=T_{a}+\left(I_{(t)} \tau \alpha / U_{L}\right)\left(1-\eta_{c} / \tau \alpha\right)
\end{gathered}
$$

Where, the transmission-absorption coefficient $\tau \alpha$ and the overall heat transfer coefficient $U$ are considered as 0.86 and $0.8 \mathrm{~W} / \mathrm{m}^{2 \circ} \mathrm{C}$, respectively [33].

\section{Results and Discussions}

Experiments were carried out between April and September 2011 in atmospheric air conditions of Konya province. The highest radiation occurred day on July 25 is taken and analyses are completed. PV cell temperature is directly proportional to solar radiation as shown in Figure 3. It is observed that for each $100 \mathrm{~W} / \mathrm{m}^{2}$ increase in solar radiation value of $\mathrm{PV} / \mathrm{T}$ and $\mathrm{PV}$ modules cell temperature have increased about $1.2{ }^{\circ} \mathrm{C}$ for PV/T system and $5.4{ }^{\circ} \mathrm{C}$ for PV system, respectively. Maximum cell temperature of PV module happens as $65{ }^{\circ} \mathrm{C}$ while $\mathrm{PV} / \mathrm{T}$ cell temperature is decreased to $32{ }^{\circ} \mathrm{C}$ at time 13:00 on 
July 25. Radiation reaches to its highest value at 13:00 and then it decreases again. Cell temperature of the PV system increases with increasing solar radiation where variation of $\mathrm{PV} / \mathrm{T}$ cell temperature is kept in the range of 20-30 ${ }^{\circ} \mathrm{C}$.

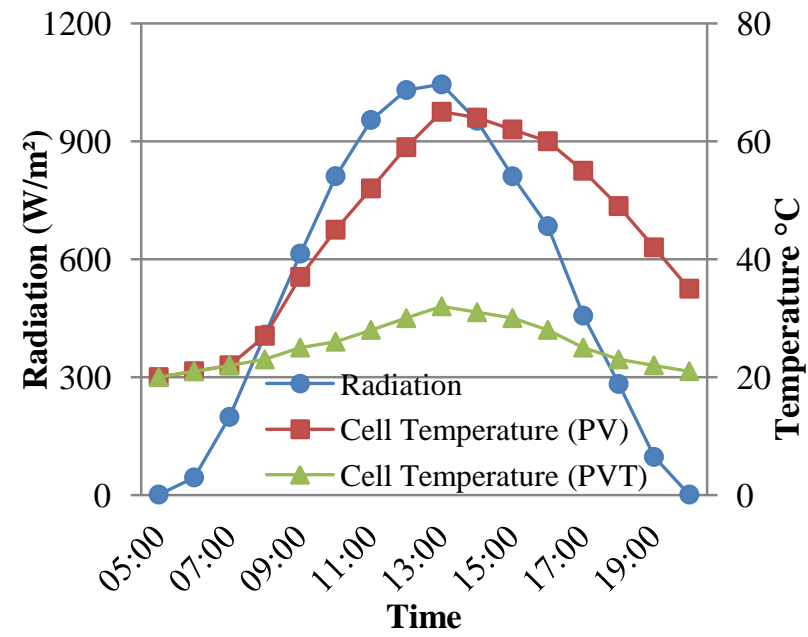

Fig. 3. Solar Radiation and cell temperatures of PV and PV/T on July 25, 2011

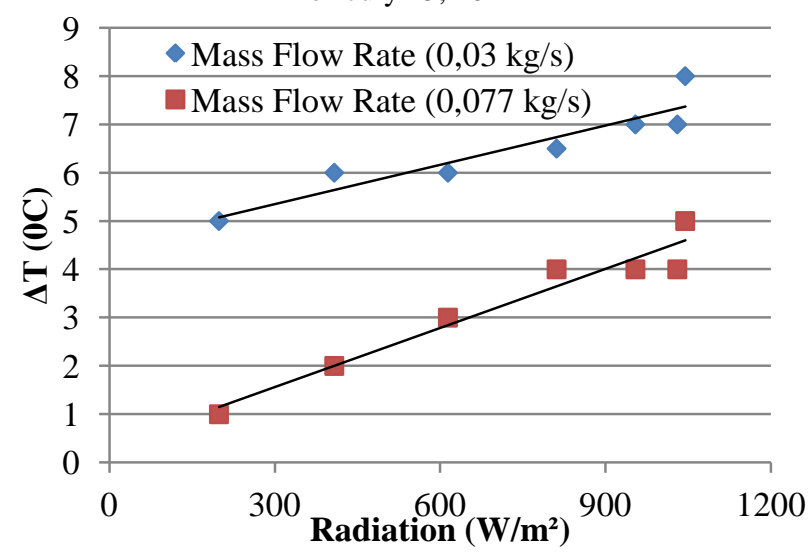

Fig. 4. Temperature difference of PV/T water collector with two different flow rates and solar radiation.

The variation of temperature difference between the inlet and outlet water temperature $\left(\mathrm{T}_{\mathrm{fi}}-\mathrm{T}_{\mathrm{fo}}\right)$ of $\mathrm{PV} / \mathrm{T}$ collector for mass flow rate values of $0.030 \mathrm{~kg} / \mathrm{s}$ and $0.077 \mathrm{~kg} / \mathrm{s}$ against different solar radiation values is presented in Figure 4. For each $100 \mathrm{~W} / \mathrm{m}^{2}$, increase in solar radiation temperature difference between inlet and outlet temperature for $0.030 \mathrm{~kg} / \mathrm{s}$ and $0.077 \mathrm{~kg} / \mathrm{s} \mathrm{mass}$ flow rates are found to be $0.61{ }^{\circ} \mathrm{C}$ and $0.43{ }^{\circ} \mathrm{C}$, respectively. As seen, the temperature difference decreases with increasing the mass flow rate and increases with increasing radiation amount. The trend relation between the temperature difference and radiation are obtained and given in table 3.

Table 3. Thermal efficiency formulas of PV/T collector.

\begin{tabular}{|l|l|}
\hline Mass flow rate & Formula \\
\hline $0.03 \mathrm{~kg} / \mathrm{s}$ & $\eta_{\iota}=0.49-4.58 \Delta T / I_{(t)}$ \\
\hline $0.077 \mathrm{~kg} / \mathrm{s}$ & $\eta_{\iota}=0.51-5.87 \Delta T / I_{(t)}$ \\
\hline
\end{tabular}

During the experiments performed between April and September 2011, PV module temperature varies between $50^{\circ} \mathrm{C}$ and $66^{\circ} \mathrm{C}$ while PV/T values varies between $30{ }^{\circ} \mathrm{C}$ and $45{ }^{\circ} \mathrm{C}$ for about $1000 \mathrm{~W} / \mathrm{m}^{2}$ solar radiation. The maximum electricity efficiency of $\mathrm{PV}$ and $\mathrm{PV} / \mathrm{T}$ system are obtained as $11.5 \%$ and $13.6 \%$, respectively, as shown in figure 5. Comparison of maximum efficiency PV/T efficiency yields $18.26 \%$ greater than the PV's efficiency.

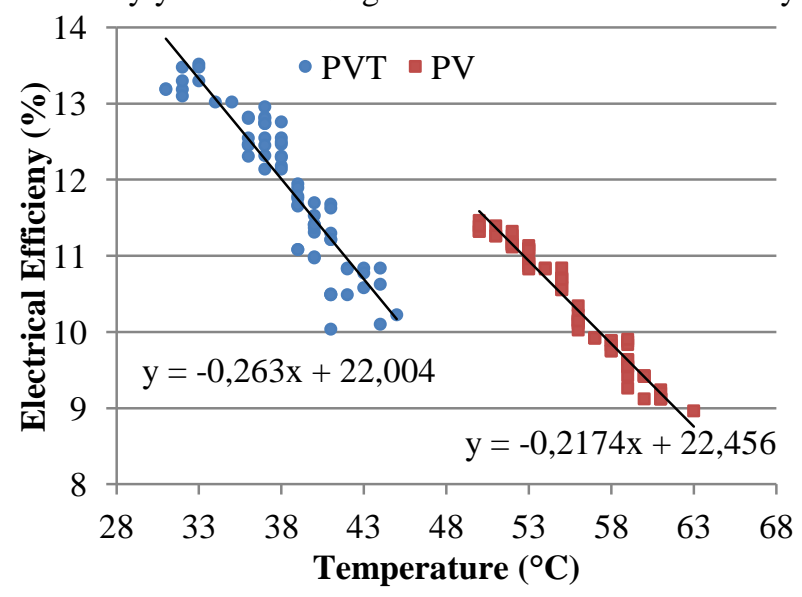

Fig. 5. Variation of electrical efficiency versus cell temperature for $\mathrm{PV}$ and $\mathrm{PV} / \mathrm{T}$ at $1000 \mathrm{~W} / \mathrm{m}^{2}$ solar radiation assumption condition

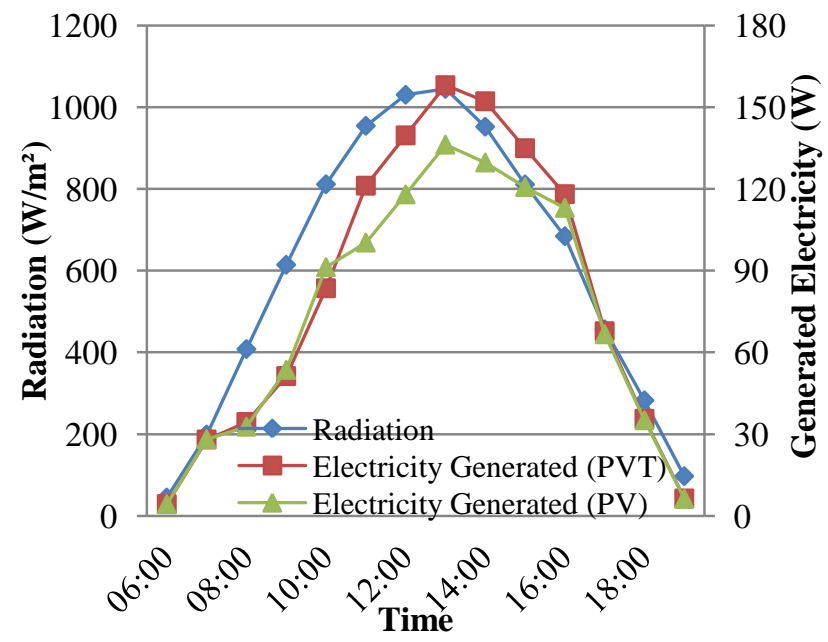

Fig. 6. Generated Electricity by PV and PV/T system during the day of April 25, 2011.

Generated electricity rates from $\mathrm{PV}$ and $\mathrm{PV} / \mathrm{T}$ collector during the day are calculated as $1030 \mathrm{Wh}$ and $1135 \mathrm{Wh}$, respectively while the total solar radiation is $8390 \mathrm{Wh} / \mathrm{m}^{2}$ day on 25 July 2011. Total electricity generation efficiencies of PV/T and PV models are found to be $13.5 \%$ and $12.4 \%$, respectively shown in figure 6 . Total daily produced energy by $\mathrm{PV} / \mathrm{T}$ system is approximately $10 \%$ higher than standard PV system. Variation of the electricity generation in figure 6 has similar trend and the maximum values of radiation, PV and PV/T systems occurs at time 13:00. It is worth noting that theoretical calculation results according to the radiation amounts have very close agreement with the experimental results. However, the difference may be caused by the module connection losses, cable losses and measurement errors. 


\section{Conclusions}

In this study, the effect of water cooling system on the photovoltaic module for improving the conversation performance was examined. The results show that in the case of the PV module temperature is $65^{\circ} \mathrm{C}$, electrical efficiency of the PV module is $8 \%$. Using of active cooling technique, the electrical efficiency of PV module according to the experimental results presents a meaningful recovery. The maximum electrical efficiency of PV module in this context was found to be $13.6 \%$. It is realized that the optimum heat transfer occurs from PV modules into the water for mass flow rate of $0.03 \mathrm{~kg} / \mathrm{s}$. Thermal performance of $\mathrm{PV} / \mathrm{T}$ collectors is calculated by means of experimental results and formula and the maximum thermal efficiency of the system was found to be $51 \%$. Variation of the electricity generation has similar trend and the maximum values of radiation, $\mathrm{PV}$ and $\mathrm{PV} / \mathrm{T}$ systems occurs at time 13:00.The maximum electricity efficiency of PV and PV/T system are $11.5 \%$ and $13.6 \%$, respectively. Generated electricity amounts from the PV and $\mathrm{PV} / \mathrm{T}$ collector are $1030 \mathrm{Wh}$ and $1135 \mathrm{Wh}$, respectively while the total solar radiation is 8390 $\mathrm{Wh} / \mathrm{m}^{2}$ day on 25 July 2011. On the other hand, high operating temperatures cause the shorten life cycle of the PV module due to damaging the module material. This situation has been substantially eliminated by cooling the PV cell. For this reason, prolonged payback time of the PV system, shortening the life of the materials used in PV modules, are among the causes of occurrence high temperature. The results show that PV/T systems can produce more electricity at the same, or in some aspects even less environmental impact than PV systems. Since the PV/T systems also deliver heat, environmental impact per unit energy delivered should be less than for regular PV-systems.

\section{Acknowledgements}

The authors would like to acknowledge the funding and providing facility of Solimpeks company board (www.solimpeks.com.tr) and Selcuk University's Scientific Research Project Contract No: 11201039. This study is prepared from Celalettin Bakir's Master of Science Thesis.

\section{References}

1. G. N. Tiwari, S. Dubey, Fundamentals of Photovoltaic Modules and Their Applications, RSC Publishing, Cambridge (2010)

2. S. A. Kalogirou, Y. Tripanagnostopoulos, Energy Conversion and Management 47, 3368-3382 (2006)

3. P. Dupeyrat, C. Me'ne'zo, M. Rommel, H-M, Henning, Solar Energy 85, 1457-1468 (2011)

4. J. Ji, J-P. Lu, T-T. Chow, W. He, G. Pei, Applied Energy 84, 222-237 (2007)

5. M. A. Hasan, K Sumathy, Renewable and Sustainable Energy Reviews 14, 1845-1859 (2010)

6. IEA solar heating and cooling programme; (2007)
7. B. Sandnes, J. Rekstad, Solar Energy 72 (1), 63-73 (2002)

8. Y. Tripanagnostopoulos, T. Nousia, M. Souliotis, P. Yianoulis, Solar Energy 72, 217-234 (2002)

9. G. Fraisse, C. Me'ne'zo, K. Johannes, Solar Energy 81, 1426-1438 (2007)

10. J. S. Coventy, Solar Energy 78, 211-222 (2005)

11. J. I. Rosell, X. Vallverdu, M. A. Lechon, M. Ibanez, Energy Conversion and Management 46, 3034-3046 (2005)

12. P. G. Charalambous, G. G. Maidment, S. A. Kalogirou, Applied Thermal Engineering 27, 275286 (2007)

13. H. A. Zondag, W. G. J. van Helden, PV in Europe From PV Technology to Energy Solutions Conference and Exhibition, Rome, Italy (2002)

14. T. T. Chow, Applied Energy 87, 365-379 (2010)

15. A. Ibrahim, M. Y. Othman, M. H. Ruslan, S. Mat, K. Sopian, Renewable and Sustainable Energy Reviews 15, 352-365 (2011)

16. T. Fujisawa, T. Tani, Solar Energy Materials and Solar Cells 47, 135-148 (1997)

17. T. T. Chow, G. Pei, K.F. Fong, Z. Lin, A.L.S. Chan, J. Ji, Applied Energy 86, 310-316 (2009)

18. H.A. Zondag, D.W. de Vries, W.G.J. van Helden, R.J.C van Zolingen, A.A. van Steenhoven, Solar Energy 74, 253-269 (2003)

19. T.T. Chow, W. He, J. Ji, Solar Energy; 80, 298-306 (2006)

20. K. Sopian, K. S. Yigit, H. T. Liu, S. Kakac, T. N. Veziroglu. Energy Conversion and Management, 37 (11), 1657-1670 (1996)

21. A.A. Hegazy, Energy Conversion and Management 41, 861-881 (2000)

22. A. Tiwari, M. S. Sodha, Renewable Energy 31, 2460-2474 (2006)

23. Y. B. Assoa, C. Menezo, G. Fraisse, R. Yezou, J. Brau, Solar Energy 81, 1132-1143 (2007)

24. S. Dubey, G. N. Tiwari, Solar Energy 82, 602-612 (2008)

25. E. Erdil, M. Ilkan, F. Egelioglu, Energy; 33, 12411245 (2008)

26. P. Gang, F. Huide, Z. Tao, J. Jie, Solar Energy, 85 5, 911-921 (2011)

27. T. Bergene, O.M. Løvvik. Solar Energy; 55, 453-62 (1995)

28. W. Hea, T.T. Chow, J. Jia, J. Lua, G. Peia, L.S. Chan, Applied Energy 83(3), 199-210 (2006)

29. J. A. Duffie, W. Beckman, Solar Engineering of Thermal Processes, John Wiley and Sons, New York (1991)

30. G. N. Tiwari, Solar Energy: Fundamentals, Design, Modeling and Applications, Narosa Publishing House, New Delhi (2004)

31. G. Vokas, N. Christandonis, F. Skittides, Solar Energy 80(5), 607-615 (2006)

32. E. Radziemska, Progress in Energy and Combustion Science, vol. 29, no. 5, 407-424 (2003)

33. J.A. Duffie, W.A. Beckman, Solar Engineering of Thermal Processes, New York, (1980). 